\title{
INDICAÇÕES BIBLIOGRÁFICAS
}

DOI: http://dx.doi.org/10.1590/So034-759020140412

\section{História social dos esportes}

Bernardo Buarque de Hollanda | bernardo.hollanda@fgv.br

Até os anos 1980, costumava-se dizer que os esportes eram um tema menor no campo das Ciências Sociais. Afora os ensaios de Antropologia Social e os trabalhos da área de Educação Física, pouco interesse era dispensado à temática, que padecia de uma condição de inferioridade diante das macroquestões econômicas, políticas e sociais. Desde a década de 1990, no entanto, o quadro vem-se alterando substantivamente, com o crescimento gradual, compacto e interdisciplinar dos estudos sobre a história e a sociologia dos esportes. Isso pode ser observado por meio da formação de diversos grupos, núcleos e laboratórios consagrados ao assunto nas Ciências Humanas e cadastrados no CNPq. Em virtude de tal ascensão, Bernardo Buarque de Hollanda (pesquisador do CPDOC e professor da Escola de Ciências Sociais - FGV) indica livros sobre o campo esportivo.

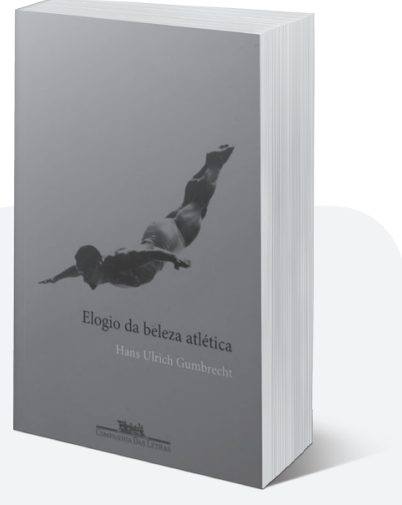

\section{ELOGIO DA BELEZA ATLÉTICA}

Hans Ulrich Gumbrecht. São Paulo: Companhia das Letras, 2007. 184 p.

O pensador Hans Ulrich Gumbrecht é bem conhecido do público brasileiro, em virtude de sua colaboração em jornais nacionais. Originalmente intitulada In praise of athletic beauty, a obra sistematiza seu pensamento estético acerca do fenômeno esportivo. A prática e a fruição dos esportes na modernidade secularizada e na cultura contemporânea desencantada são refletidas por Gumbrecht à luz de sua experiência com o universo atlético-corporal nos Estados Unidos.

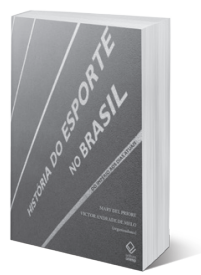

HISTÓRIA DO ESPORTE NO BRASIL: Do Império aos dias atuais Mary Del Priore e Victor Andrade de Melo (Orgs.). São Paulo: Unesp, 2009. 566 p.

A coletânea apresenta um dos painéis históricos mais completos na abordagem das práticas esportivas no Brasil, entre os séculos XIX e XXI. Se o campo configura-se, em seus primórdios, na organização das corridas de cavalo e das competições de regatas, o fio condutor do livro acompanha a passagem de um cenário poliesportivo à chamada mania galvanizante do futebol, que se torna modalidade hegemônica já na década de 1910.

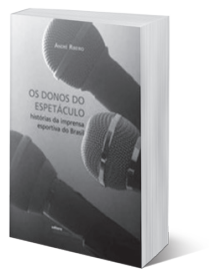

\section{OS DONOS DO ESPETÁCULO: Histórias da imprensa esportiva no Brasil} André Ribeiro. São Paulo: Terceiro Nome, 2007. 328 p.

O livro é rico em informações na apresentação da evolução dos esportes como fenômeno comunicativo, em particular na contextualização da imprensa escrita, falada e televisada no País, durante o século XX. Protagonistas de jornais, estações de rádio e canais de televisão são revelados ao grande público, em obra que preenche uma série de lacunas na descrição e análise da história social dos esportes, pari passu à cultura de massas no Brasil.

\section{PESQUISA HISTÓRICA E HISTÓRIA DO ESPORTE}

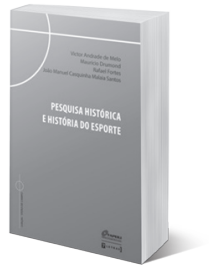

Maurício Drummond, Rafael Fortes, Victor Andrade de Melo e João Manuel Malaia Santos (Orgs.). Rio de Janeiro: 7 Letras, 2013. 192 p.

Trata-se de uma das mais importantes contribuições historiográficas à introdução dos métodos de pesquisa em história social dos esportes. Com visão panorâmica e em perspectiva comparada, estudam-se aspectos culturais, políticos e econômicos dos modos de praticar e representar as modalidades esportivas. Soma-se a essas esferas de conhecimento a presença do esporte nos meios de comunicação, nas artes, nos arquivos públicos e privados e nas fontes orais.

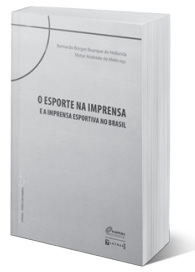

\section{O ESPORTE NA IMPRENSA E A IMPRENSA ESPORTIVA NO BRASIL}

Bernardo Borges Buarque de Hollanda e Victor Andrade de Melo (Orgs.). Rio de Janeiro: 7 Letras, 2012. 210 p.

0 projeto desta obra é reunir trabalhos monográficos de pesquisadores brasileiros sobre a história da imprensa esportiva do País. Focam-se, em especial, os jornais e as revistas que marcaram época na formação do imaginário futebolístico no Brasil. Se a pesquisa com periódicos costuma ser feita com base no levantamento e na coleta dos registros impressos, neste livro, o que prevalece é menos a fonte e mais o objeto dissecado em sua trajetória. 